\title{
Penentuan Sebaran Reservoar Belumai Sand Menggunakan Integrasi Inversi Model Based dan Atribut RMS Pada Lapangan "TERATAI" Cekungan Sumatera Bagian Utara
}

\author{
Rudi Hidayat $^{1}$, Elistia Liza Namigo ${ }^{1}$, Muhammad Marwan ${ }^{2}$ \\ ${ }^{1}$ Laboratorium Fisika Bumi, Jurusan Fisika, FMIPA, Universitas Andalas \\ Kampus Unand, Limau Manis, Padang, 25163 \\ ${ }^{2}$ PT.Pertamina EP Asset 1 Field Jambi, Ka.Asam, Kota Jambi, 36128
}

\section{Info Artikel}

\section{Histori Artikel:}

Diterima: 3 Oktober, 2019

Direvisi: 6 November, 2019

Diterbitkan: 1 Maret, 2020

\section{Kata kunci:}

Belumai sand impedansi akustik inversi model based

karakteristik reservoar batupasir $R M S$ amplitudo

\section{Keywords:}

Belumai sand acoustic impedance model based inversion sandstone reservoir characterization RMS amplitude

\section{Penulis Korespondensi:}

Elistia Liza Namigo

Email:

elistializanamigo@yahoo.com

\begin{abstract}
ABSTRAK
Telah dilakukan karakterisasi reservoar Belumai sand menggunakan integrasi seismik inversi model based dan atribut RMS menggunakan software Hampson-Russel dan Petrel pada horizon "H" struktur "Duku" dan "Durian" Lapangan "TERATAI" Cekungan Sumatera Bagian Utara. Data seismik yang digunakan merupakan data seismik non-preserved 3D PSTM, data sumur RDH-001, RDH-002, RDH-003, RDH-04 dan RDH-06 yang memiliki kelengkapan data log (checkshot, sonic, density, dan porosity). Tracing horizon menunjukkan dua antiklin dengan arah baratlaut-tenggara. Hasil analisis inversi menunjukkan bahwa sebaran AI pada struktur "Duku" berkisar dari 10.553-11.297 $(\mathrm{m} / \mathrm{s}) *(\mathrm{~g} / \mathrm{cc})$ sedangkan sebaran AI pada struktur "Durian" berkisar dari $9.678-11.219(\mathrm{~m} / \mathrm{s}) *(\mathrm{~g} / \mathrm{cc})$. Hasil analisis atribuT menunjukkan nilai berkisar dari 4.000-12.000 $(\mathrm{mm} / \mathrm{sec})$ di sekitar sumur. Zona reservoar pada horizon "H" terindikasikan sebagai porous sand dan berpotensi menjadi hidrokarbon ke arah utara dan timur laut.
\end{abstract}

Belumai Sand reservoir characterization has been conducted by using integration of model based inversion and RMS attribute analysis on horizon " $H$ " of "Duku" and "Durian" structureS, "TERATAI" field in North Sumatra Basin. The data were processed by Hampson-Russel and Petrel software. The seismic data used were non-preserved $3 D$ PSTM and well data of RDH-001, RDH-002, RDH-003, RDH-04 and RDH-06 that are completed with log data (checkshot, sonic, density, and porosity). The tracing horizon result shows two parts of anticline with the orientation of northwest-southeast. The analysis result using inversion shows that AI determination on "Duku" structure approximate range of $10.553-11.297(\mathrm{~m} / \mathrm{s}) *(\mathrm{~g} / \mathrm{cc})$ while the AI distribution on "Durian" structure of $9.678-11.219(\mathrm{~m} / \mathrm{s}) *(\mathrm{~g} / \mathrm{cc})$ approximate height. The result of attribute analysis shows that approximate range of 4.000-12.000 $(\mathrm{mm} / \mathrm{sec})$ around the well. The reservoir zone in horizon " $H$ " was indicated as porous sand and potentially become hydrocarbons to the north and northeast.

\section{PENDAHULUAN}

Batuan reservoar dapat diketahui posisinya untuk dijadikan sumber hidrokarbon yang mengandung minyak dan gas bumi. Secara umum ada dua jenis batuan reservoar hidrokarbon yaitu jenis batuan batupasir (sandstone) dan batuan gamping atau batuan karbonat (Koesoemadinata, 1980). 
Salah satu cara yang dapat dilakukan untuk mengetahui gambaran karakter reservoar dari batuan reservoar adalah dengan karakterisasi reservoar pada batuan tersebut.

Karakterisasi reservoar merupakan suatu proses untuk menjabarkan karakter batuan reservoar secara kualitatif dan kuantitatif dengan menggunakan semua data yang ada (Sukmono, 2002). Tujuan dari karakterisasi reservoar adalah untuk mendapatkan informasi dari suatu batuan reservoar dan mengoptimalisasi perolehan hidrokarbon. Burge, D.W., dkk (1998) menyatakan bahwa karakterisasi reservoar dengan menggabungkan semua data yang ada termasuk data seismik, petrofisika dan geologi akan memberikan distribusi parameter reservoar seperti: porositas dan saturasi dengan lebih baik.

Secara umum, teknik yang digunakan dalam mengkarakterisasi batuan reservoar yaitu interpolasi dan ektrapolasi data sumur. Data sumur ini menggambarkan keadaan bawah permukaan bumi dengan baik secara vertikal. Untuk memperoleh gambaran bawah permukaan secara lateral digunakan metode seismik refleksi (Novarie, 2009). Hasil penelitian yang dilakukan Tullailah, dkk (2015) memperlihatkan bahwa data seismik memiliki kelemahan dalam memberikan kenampakan adanya patahan dan bentuk badan reservoar. Oleh karena itu perlu dilakukan analisis atribut seismik yang dapat memperlihatkan adanya patahan dan badan reservoar secara lebih jelas.

Hasil penelitian yang dilakukan Yaman (2005) menyatakan bahwa beberapa jenis atribut memiliki sensitifitas lebih baik terhadap sifat reservoar dan beberapa atribut lainnya dalam menampilkan informasi ataupun anomali bawah permukaan bahkan sebagai DHI (direct hydrocarbon indicator). Pemilihan atribut yang tepat untuk karakterisasi reservoar akan menghasilkan gambaran geologi yang lebih baik. Data seismik konvensional hanya memberikan gambaran batas lapisan berdasarkan nilai amplitudo gelombang seismik sedangkan sifat fisis dari litologi reservoar tidak dapat terlihat jelas. Oleh sebab itu perlu dilakukan seismik inversi untuk melihat sifat fisis AI (acoustic impedance) pada lapisan itu sendiri.

Seismik inversi merupakan suatu cara untuk membuat model bawah permukaan dengan menggunakan data seismik sebagai masukan dan data sumur sebagai kontrol (Tabah, 2010). Kelebihan seismik inversi memiliki keakuratan dan resolusi vertikal yang cukup tinggi. Penerapan seismik inversi akan menghasilkan model perhitungan geologi yang mampu mendekati model geologi bumi sebenarnya dengan tingkat kesalahan yang diharapkan kecil (Arifien, 2010).

Penelitian ini dilakukan pada lapangan "TERATAI" cekungan Sumatera Bagian Utara dengan inisial struktur "Duku" dan "Durian". Integrasi inversi model based dan atribut RMS (Root Mean Square) dipakai menganalisis reservoar. Selanjutnya dilakukan interpretasi dan pemetaan bawah permukaan yang lebih baik dan memiliki cakupan daerah yang luas secara lateral atau horizontal, untuk mengetahui prospek kandungan hidrokarbon di suatu zona bawah permukaan pada wilayah tertentu.

\section{METODE PENELITIAN}

\subsection{Data}

Data yang digunakan dalam penelitian ini meliputi data seismik 3D tipe PSTM yang terdiri dari 1171 inline dan 1088 xline, data sumur pemboran sebanyak 5 sumur yang terdiri dari 4 sumur vertical dan 1 sumur directional, data geologi, data marker, dan data checkshot. Semua data merupakan data sekunder yang diperoleh dari Pertamina EP Asset 1 Field Jambi.

\subsection{Pengolahan Data}

Pengolahan data menggunakan seperangkat komputer yang dilengkapi dengan software Hampson-Russell dan Petrel. Sebelum melakukan pengolahan data terlebih dahulu dibuat database sebagai lokasi menyimpan project pada masing-masing software. Data yang dimasukkan berupa data sumur, data seismik, data marker, dan checkshot yang akan digunakan dalam pengolahan data.

Selanjutnya dilakukan pengolahan data agar diperoleh hasil pemodelan yang baik menggunakan teknik geofisika yaitu seismik inversi dan atribut seismik. Software Hampson-Russell digunakan untuk melakukan picking horizon, initial model dan proses seismik inversi. Software Petrel 
digunakan untuk fault picking, atribut seismik dan pembuatan peta bawah permukaan. Prosedur penelitian yang dilakukan melalui beberapa tahapan sistematis seperti Gambar 1 .

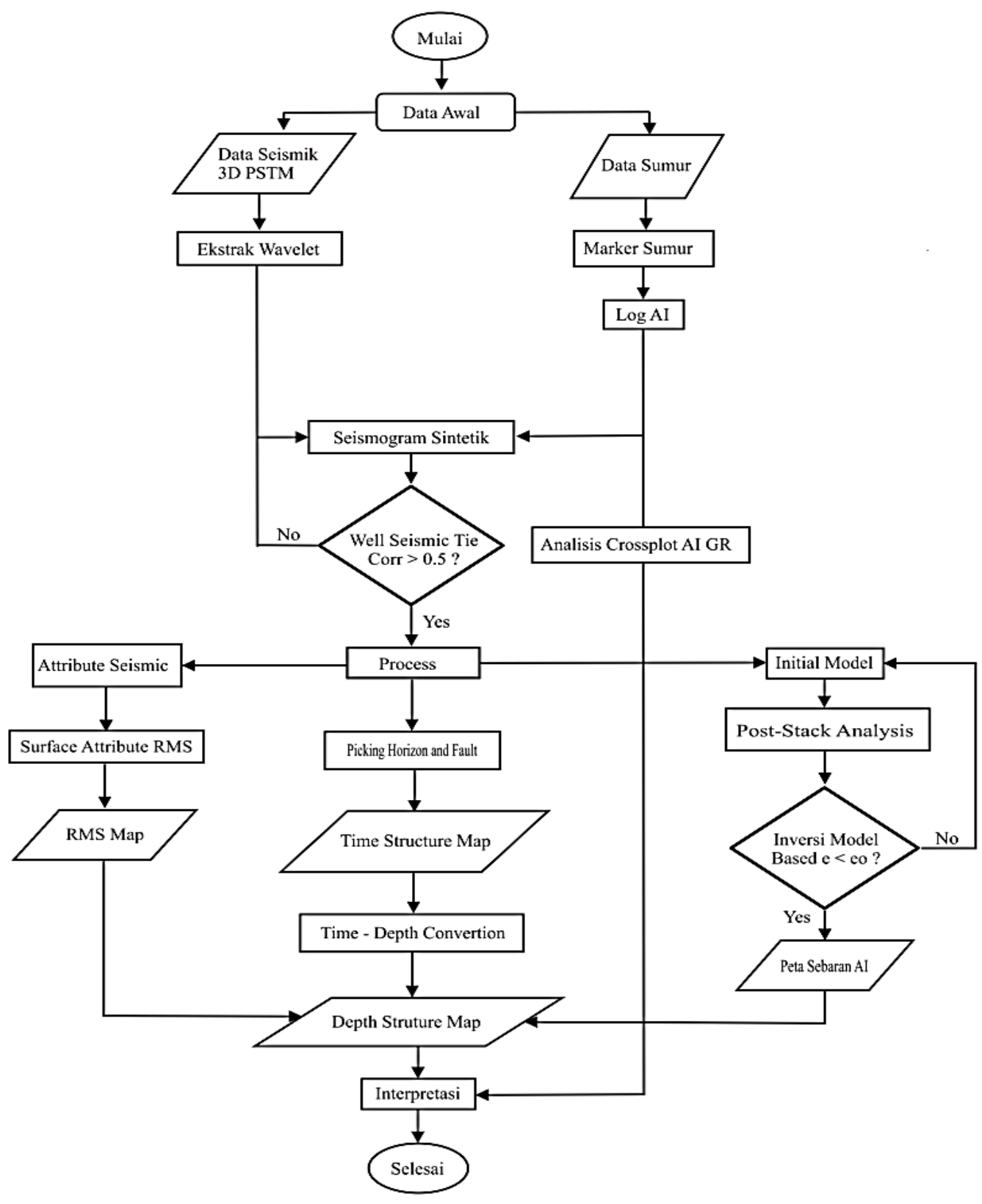

Gambar 1 Flowchart penelitian

\subsection{Tahap Interpretasi Data}

Data seismik dan data sumur dianalisis secara terpadu dari setiap hasil pengolahan data di atas untuk dievaluasi dan ditentukan prospektivitas hidrokarbon pada daerah penelitian. Selain data seismik dan data sumur, diperlukan juga data geologi regional lapangan "TERATAI" Formasi Belumai, seperti litologi formasi, sejarah pembentukan cekungan dan lain-lain. Analisis atribut seismik juga dilakukan pada penelitian ini untuk menentukan karakteristik reservoar dan penyebaran reservoar pada daerah tersebut. Pada akhirnya dapat ditentukan daerah yang mempunyai potensi hidrokarbon berdasarkan 
Hidayat dkk..: Penentuan Sebaran Reservoar Belumai Sand Menggunakan Integrasi Inversi Model Based dan Atribut RMS Pada Lapangan "TERATAI" Cekungan Sumatera Bagian Utara

interpretasi seismik struktural dan stratigrafi serta analisis atribut dan seismik inversi yang telah dilakukan.

\section{HASIL DAN DISKUSI}

\subsection{Analisis Crossplot}

Analisis crossplot digunakan untuk menentukan properti log yang akan digunakan untuk memisahkan zona reservoar dengan non reservoar. Crossplot antara log gamma ray dan p-impedance memperlihatkan harga $G R$ dapat digunakan untuk memisahkan litologi antara sand dan shale pada nilai cutoff 90 API. Hasil crossplot pada struktur "Duku" dan "Durian" dapat dilihat pada Gambar 2 dan Gambar 3.

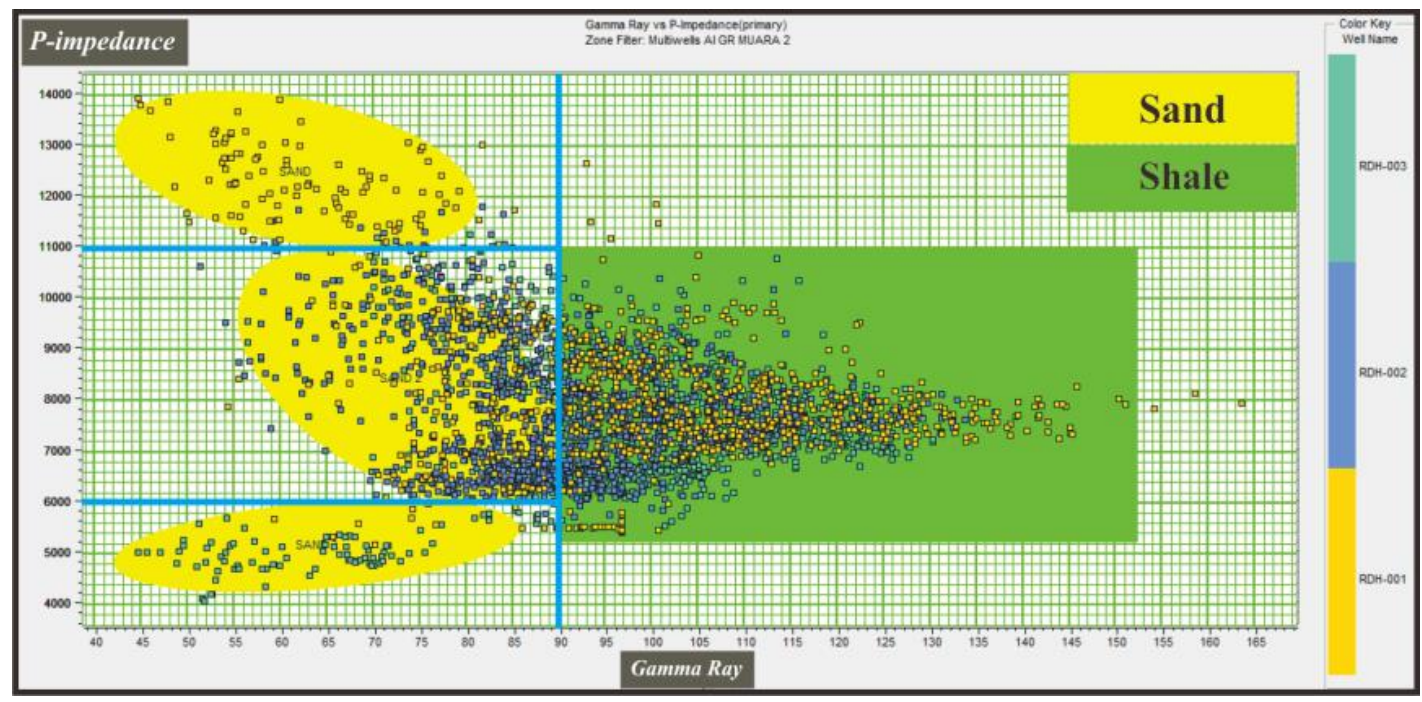

Gambar 2 Crossplot AI vs GR struktur "Duku” menggunakan marker

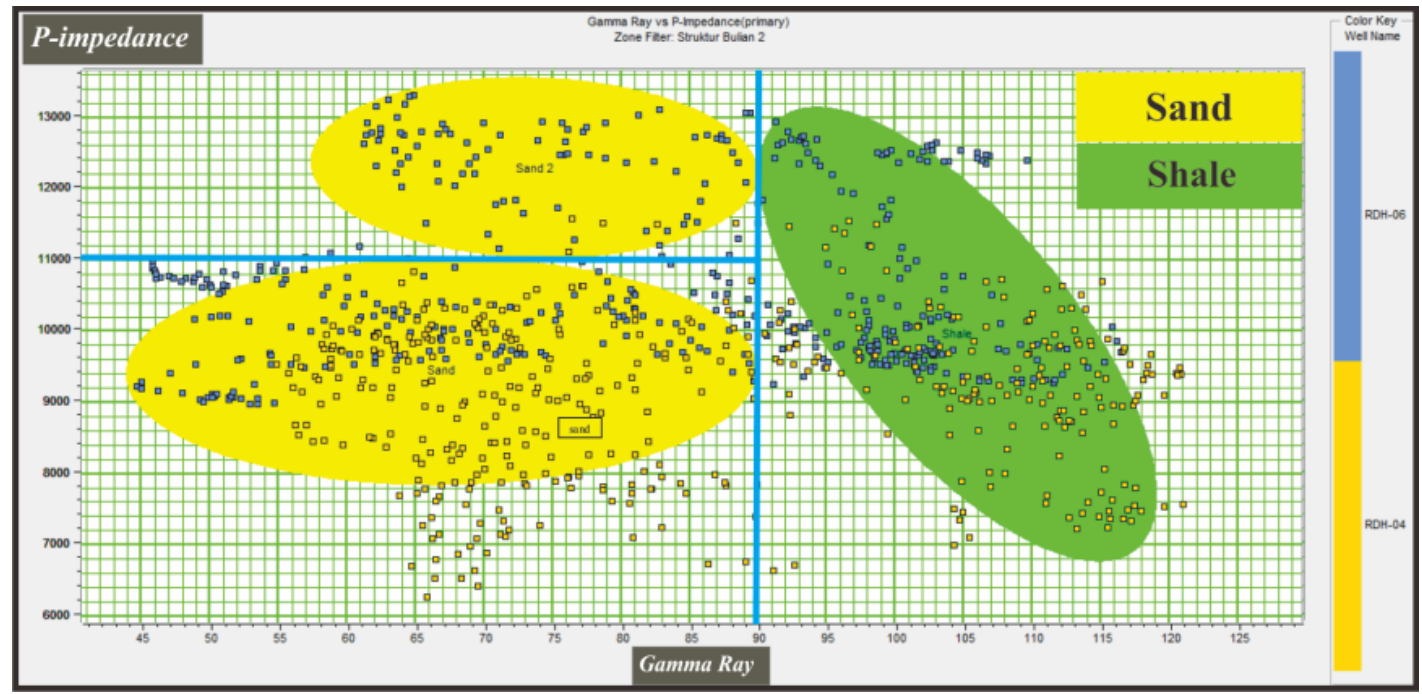

Gambar 3 Crossplot AI vs GR struktur “Durian” menggunakan marker

Hasil crossplot pada struktur "Duku" dan "Durian" menjelaskan bahwa log p-impedance dapat digunakan untuk membedakan zona reservoar yang berwarna kuning dibawah cutoff dan non reservoar berwarna hijau diatas cutoff. Warna kuning terbagi menjadi tight sand untuk nilai AI tinggi berkisar dari 11.000-13.000 $(\mathrm{m} / \mathrm{s})^{*}(\mathrm{~g} / \mathrm{cc})$ dan GR 45-90 API. Sedangkan porous sand untuk nilai AI lebih rendah berkisar dari 6.000-11.000 (m/s)*(g/cc) dan GR 56-90 API. 
Hidayat dkk..: Penentuan Sebaran Reservoar Belumai Sand Menggunakan Integrasi Inversi Model Based dan Atribut RMS Pada Lapangan "TERATAI" Cekungan Sumatera Bagian Utara

\subsubsection{Well Seismic Tie (WST)}

Sebelum dilakukan WST diperlukan koreksi checkshot untuk memindahkan domain kedalaman sumur ke kedalaman yang sebenarnya. Selanjutnya dilakukan ekstraksi wavelet menggunakan jenis statistical dari data seismik. Wavelet yang dihasilkan menggunakan parameter wavelet length $300 \mathrm{~ms}$, taper length $25 \mathrm{~ms}$ dan sample rate $2 \mathrm{~ms}$. Berikut adalah hasil dari ekstraksi wavelet seperti pada Gambar 4.

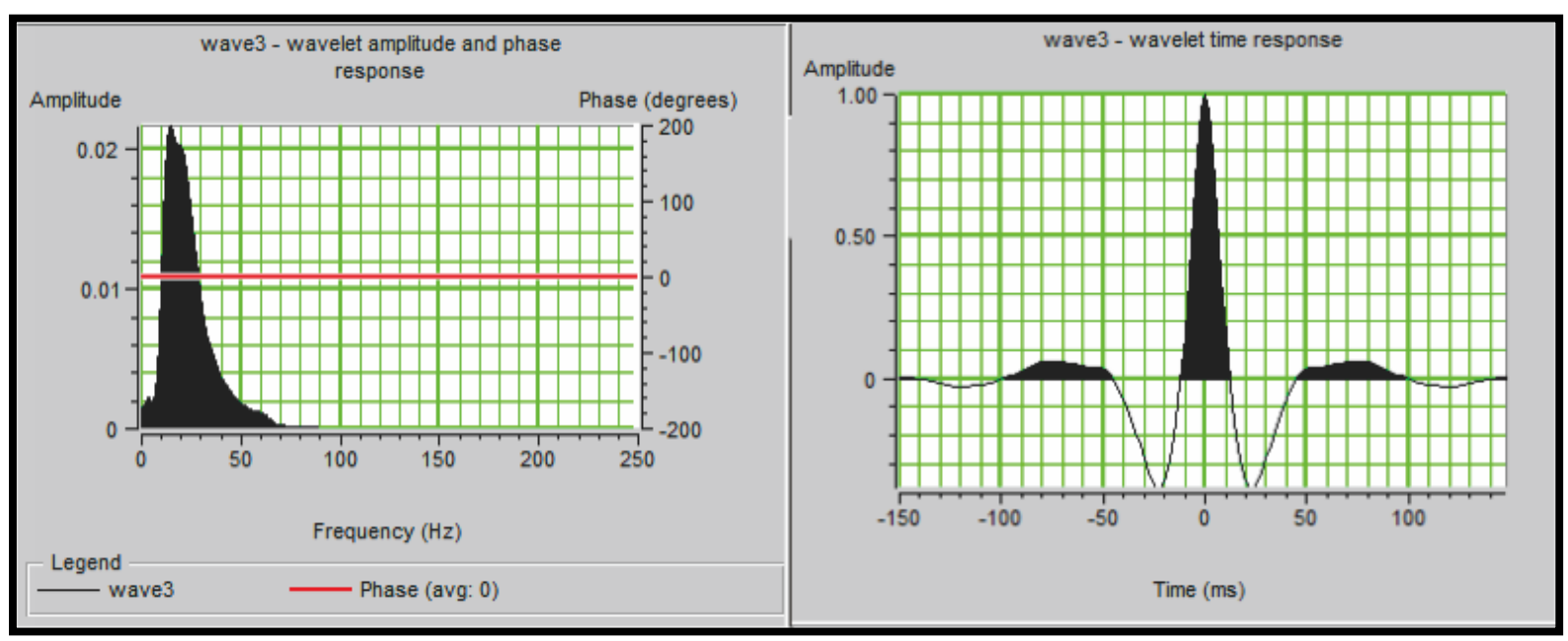

Gambar 4 (a) Hasil ektraksi wavelet (b) frekuensi wavelet

Wavelet kemudian dikonvolusi dengan log AI untuk mendapatkan seismogram sintetik. Setelah dilakukan proses stretching,squeezing dan shifting maka, akan diperoleh nilai korelasi antara seismogram sintetik terhadap trace seismik di atas nilai 0,5 dengan time shift mendekati nol. Kemiripan wavelet saat WST menunjukkan bahwa wavelet memiliki fasa dan frekuensi yang sama. Jika nilai korelasi yang diperoleh kecil maka harus dilakukan ekstraksi ulang pada wavelet yang dibuat sebelumnya. Time shift 0 sampai 1 mengindikasikan bahwa tidak ada pergeseran signifikan antara seismogram sumur dan seismogram seismik. Hasil ekstraksi wavelet time response menunjukkan wavelet zero phase, menggunakan wavelet ini korelasi yang dihasilkan cukup baik seperti Tabel 1 .

Tabel 1 Hasil korelasi pada well seismic tie

\begin{tabular}{ccc}
\hline Well Name & Correlation & Time Shift \\
\hline RDH-001 & 0,698 & 0 \\
RDH-002 & 0,238 & 0 \\
RDH-003 & 0,211 & 0 \\
RDH-04 & 0,848 & -1 \\
RDH-06 & 0,846 & 0 \\
\hline
\end{tabular}

\subsubsection{Analisis Struktur}

Hasil picking horizon secara lateral di semua line seismik lapangan "TERATAI" formasi Belumai terletak pada time 2.100-2.300 ms membentuk struktur tutupan (antiklin) disebelah barat laut dan tenggara yang ditembus masing-masing sumur seperti Gambar 5. Selain itu, didapatkan tiga peta perrmukaan zona target yaitu basement horizon $\mathrm{R}$ formasi Baong, transtition horizon $\mathrm{D}$ antara formasi Baong dan formasi Belumai dan top horizon $\mathrm{H}$ formasi Belumai. Penelitian ini difokuskan pada top horizon $\mathrm{H}$ yang diindikasikan sebagai reservoar Belumai sand pada Gambar 6. 
Hidayat dkk..: Penentuan Sebaran Reservoar Belumai Sand Menggunakan Integrasi Inversi Model Based dan Atribut RMS Pada Lapangan "TERATAI” Cekungan Sumatera Bagian Utara

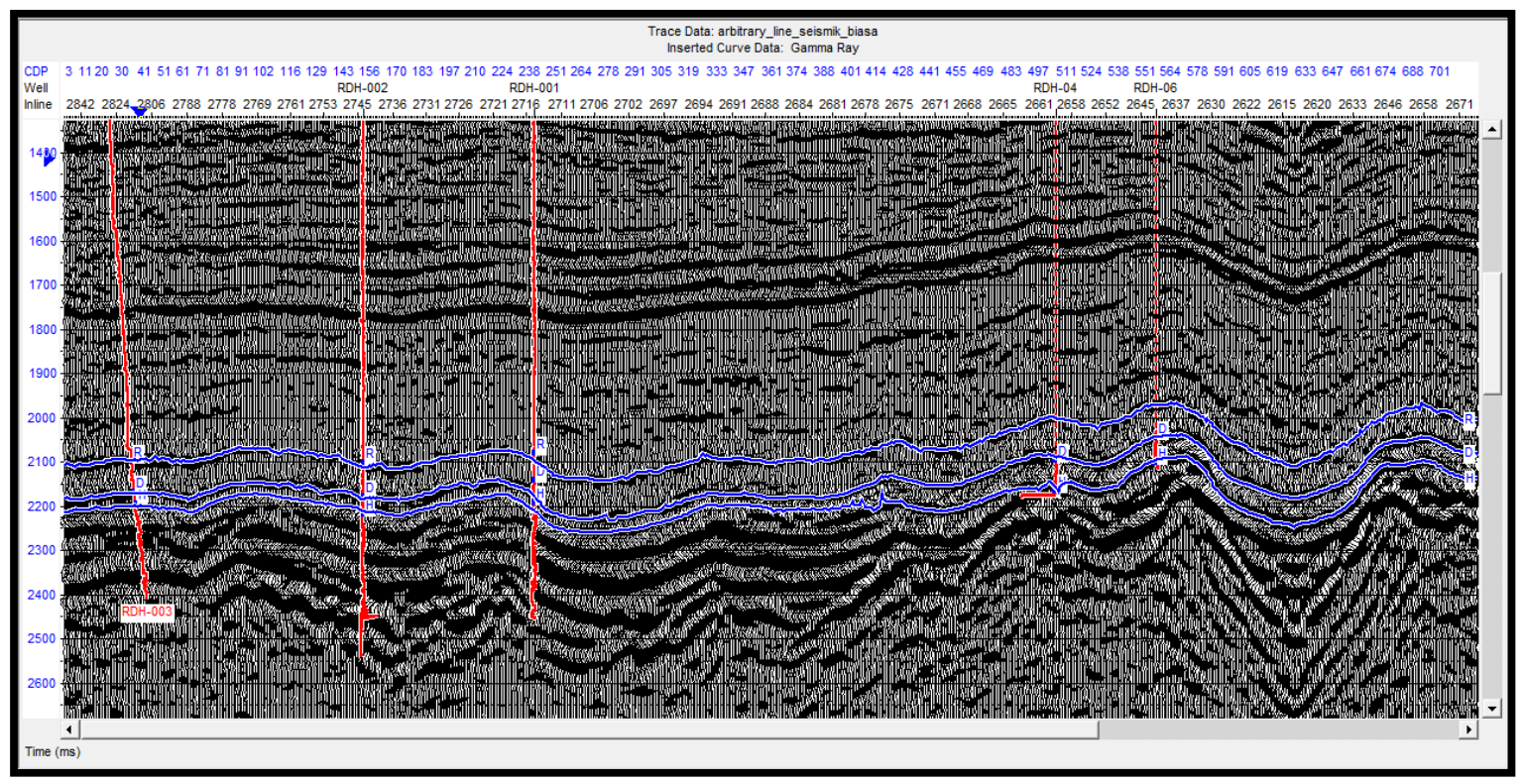

Gambar 5 Picking horizon seismik lapangan "TERATAI"
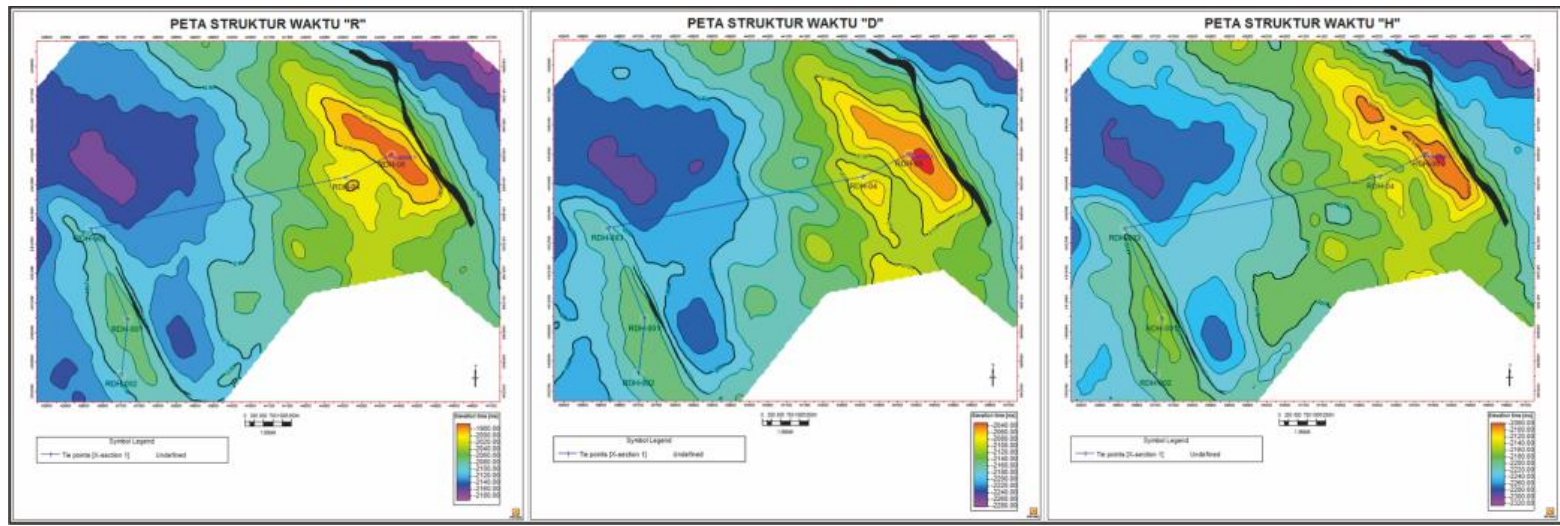

Gambar 6 Peta permukaan horizon R,D dan $\mathrm{H}$

Gambar 7 menunjukkan peta time structure dan depth strucutre dari horizon $\mathrm{H}$ formasi Belumai. Hasil pemetaan time strucutre horizon $\mathrm{H}$ memberikan interval TWT antara -2080 sampai 2320 ms dan interval TVD antara -2.400 sampai -2.940 meter. Antiklin sebelah barat ditembus oleh sumur-sumur RDH-001, RDH-002 dan RDH-003 di struktur "Duku", sedangkan sebelah timur ditembus oleh sumur-sumur RDH-04 dan RDH-06 di struktur "Durian". Analisis struktur terdapat juga patahan yang berorientasi dari tenggara-timur laut (SW-NE) terlihat jelas memotong kedua struktur yang ditandai oleh garis berwarna hitam. 


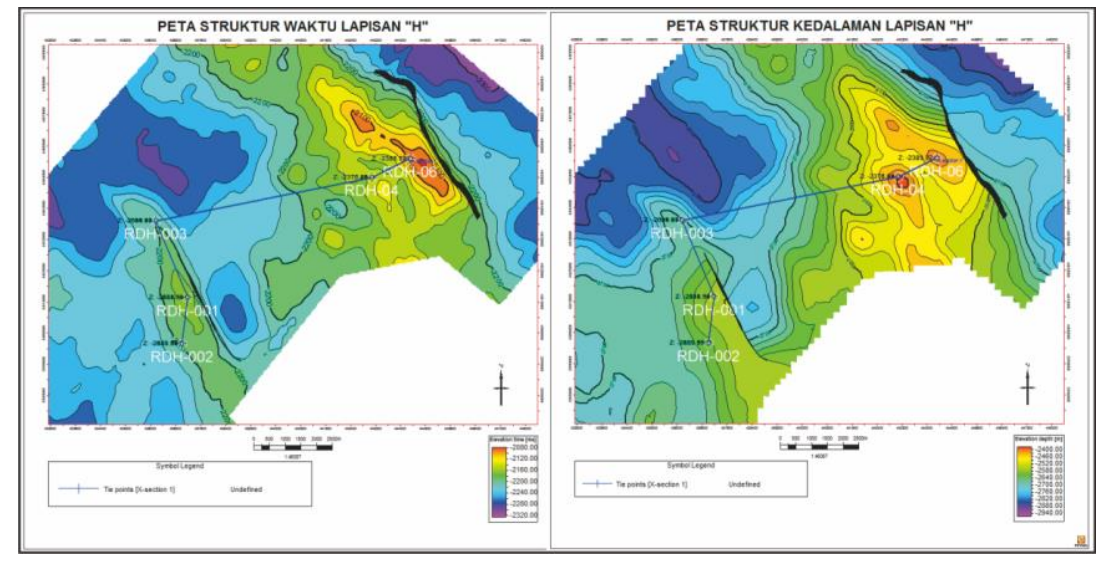

Gambar 7 Peta (a) time structure TWT (b) depth structure TVD horizon $\mathrm{H}$

\subsubsection{Analisis Inversi Model Based}

Sebelum dilakukan proses inversi diperlukan post-stack analysis pada model awal yang telah dibuat dengan menggunakan parameter tiga metode inversi yaitu model based, bandlimited dan LP sparse spike. Hasilnya diperoleh rata-rata nilai error terkecil untuk korelasi terbaik yaitu inversi model based pada proses selanjutnya. Pada penelitian ini dibatasi pada jenis inversi seismik model based hard constraint karena paling baik dibandingkan kedua jenis inversi lain dapat dilihat hasil analisis pada Tabel 2.

Tabel 2 Hasil post-stack analysis pada model awal

\begin{tabular}{cccc}
\hline Well Name & Inversion Type & Correlate & Error \\
\hline RDH-001 & Model Based & 0,943053 & 0,343972 \\
& Bandlimited & 0,829462 & \\
RDH-002 & LP Sparse Spike & 0,947638 & 0,336466 \\
& Model Based & 0,981216 & 0,198649 \\
& Bandlimited & 0,918109 & \\
RDH-003 & LP Sparse Spike & 0,983276 & 0,193905 \\
& Model Based & 0,984943 & 0,174287 \\
RDH-04 & Bandlimited & 0,906445 & \\
& LP Sparse Spike & 0,972407 & 0,258603 \\
& Model Based & 0,993536 & 0,113674 \\
RDH-06 & Bandlimited & 0,974641 & \\
& LP Sparse Spike & 0,98291 & 0,185218 \\
& Model Based & 0,994494 & 0,105531 \\
& Bandlimited & 0,973555 & \\
\hline
\end{tabular}

Hasil inversi model based pada lapangan "TERATAI" menunjukkan nilai AI berkisar dari 5.572-16.459 (m/s)*(g/cc). Nilai AI 5.572-11.469 (m/s)*(g/cc) dikategorikan dengan litologi sand dan nilai AI 11.469-16.459 (m/s)*(g/cc) dikategorikan litologi shale. Pada struktur "Duku" sumur RDH001 mempunyai nilai AI berkisar $10.700(\mathrm{~m} / \mathrm{s}) *(\mathrm{~g} / \mathrm{cc})$, sedangkan sumur RDH-002 mempunyai nilai AI berkisar $11.000(\mathrm{~m} / \mathrm{s}) *(\mathrm{~g} / \mathrm{cc})$ dan sumur RDH-003 mempunyai nilai AI berkisar 10.500 $(\mathrm{m} / \mathrm{s}) *(\mathrm{~g} / \mathrm{cc})$. Pada struktur "Durian" sumur RDH-04 mempunyai nilai AI berkisar $8.600(\mathrm{~m} / \mathrm{s})^{*}(\mathrm{~g} / \mathrm{cc})$ dan sumur RDH-06 mempunyai nilai AI berkisar $10.400(\mathrm{~m} / \mathrm{s}) *(\mathrm{~g} / \mathrm{cc})$. Dimana semakin ke warna ungu menyatakan semakin cepat atau tinggi nilai velocity gelombang seismik saat menembus lapisan batuan. Sumur-sumur penelitian di struktur "Duku" dan struktur "Durian" memiliki velocity rendah sampai menengah sehingga dapat dikelompokkan ke dalam tipe batupasir yang sifatnya porous. 
Interpretasi AI dilakukan melalui slicing AI dengan window 4 ms dibawah horizon $\mathrm{H}$ kemudian di overlay ke peta depth structure menggunakan ekstrak value pada penampang AI seperti Gambar 8.

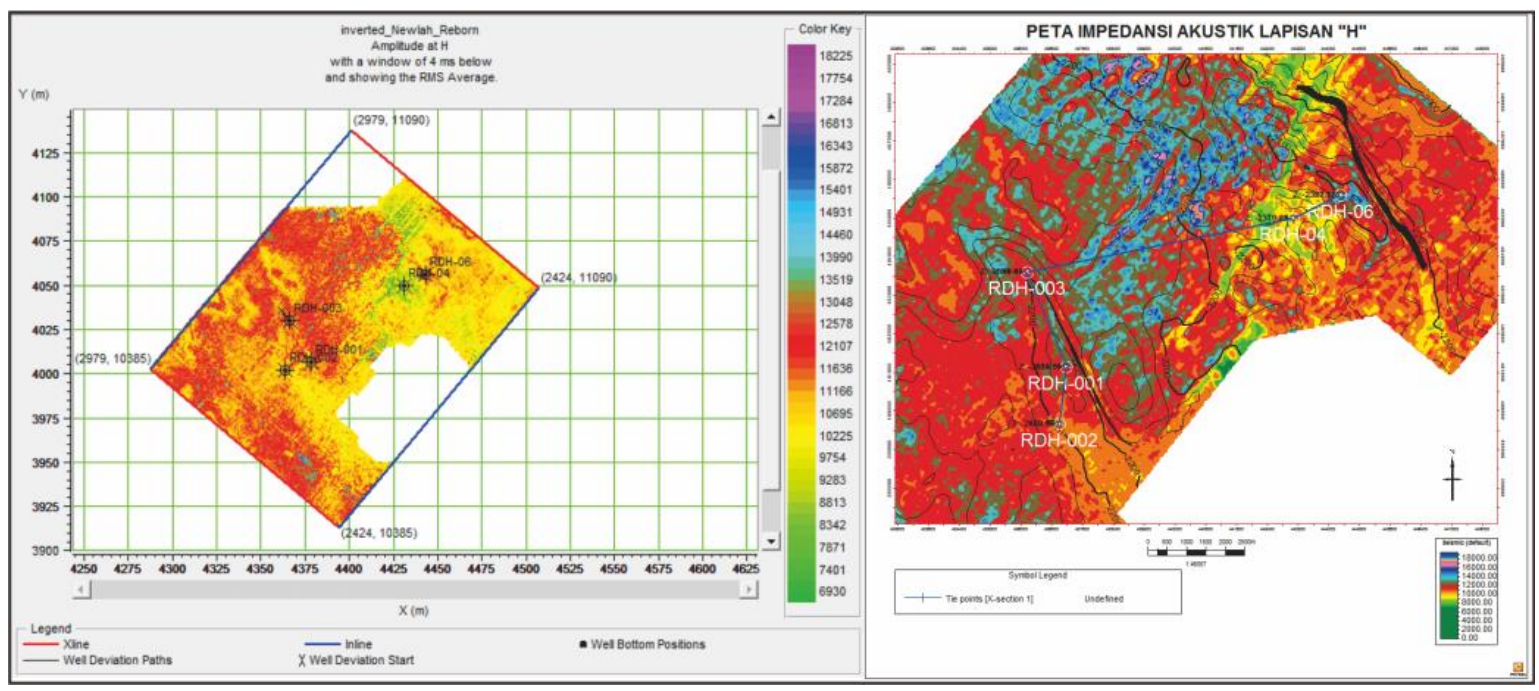

Gambar 8 (a) Slice AI window 4 ms dibawah horizon $\mathrm{H}$ (b) Overlay depth structure dengan ekstrak value AI

\subsubsection{Analisis Atribut Seismik}

Sebaran nilai RMS (Root Mean Square) amplitudo pada horizon H menunjukkan anomali secara lateral yang terlihat jelas. Atribut $R M S$ amplitudo sangat sensitif terhadap perubahan nilai amplitudo yang signifikan. Nilai amplitudo rendah ditunjukkan dengan warna biru sedangkan amplitudo tinggi ditunjukkan dengan warna merah. Pada kedua struktur "Duku" dan "Durian" seperti Gambar 9 terdapat sumur-sumur penelitian dengan nilai atribut RMS lebih rendah berkisar antara 4.000-12.000 (mm/sec) ditunjukkan dengan warna biru. Daerah sumur memiliki litologi batupasir dengan porositas lebih besar, oleh karena itu nilai atributnya lebih rendah. Nilai atribut yang rendah ini mengindikasikan litologi batupasir yang porous karena lebih lambat memantulkan gelombang seismik.

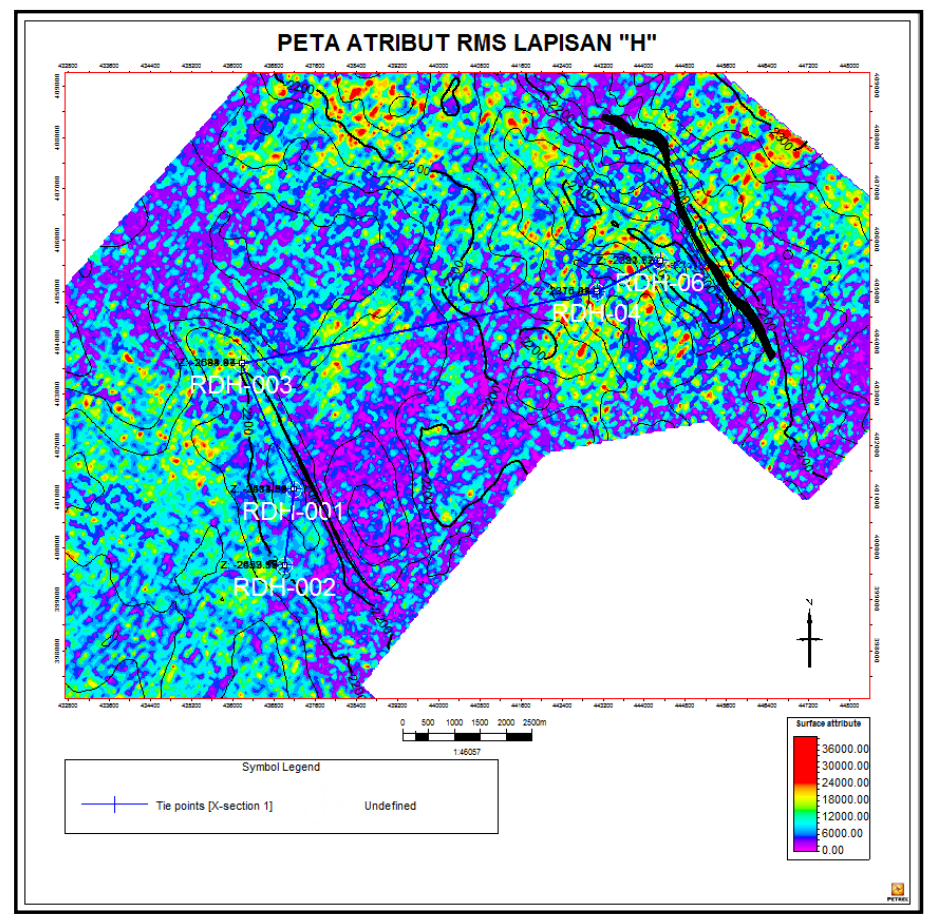

Gambar 9 Peta atribut seismik RMS amplitudo 


\section{KESIMPULAN}

Dari penelitian dapat disimpulkan bahwa picking horizon menunjukkan tutupan (antiklin) yaitu struktur "Duku" dan struktur "Durian" dengan arah barat laut dan tenggara dengan kedalaman antara 2.100-2.300 ms. Hasil crossplot log p-impedance vs GR memiliki sensitifitas yang baik dan memisahkan zona reservoar dibawah cutoff 90 API sebagai batupasir. Slicing map window size $4 \mathrm{~ms}$ dibawah horizon $\mathrm{H}$ menyatakan struktur "Duku" memiliki nilai AI berkisar antara 10.553-11.297 $(\mathrm{m} / \mathrm{s})^{*}(\mathrm{~g} / \mathrm{cc})$ dan struktur "Durian" memiliki nilai AI berkisar antara 9.678-11.219 $(\mathrm{m} / \mathrm{s}) *(\mathrm{~g} / \mathrm{cc})$. Hasil atribut RMS amplitudo menunjukkan nilai berkisar antara 4.000-12.000 (mm/sec) ttersebar ke semua arah terutama di bagian utara dan timur laut. Hasil inversi model based dan atribut RMS pada horizon $\mathrm{H}$ menunjukkan interpretasi yang saling berhubungan maka dapat kemungkinan zona reservoar hidrokarbon tersebut adalah porous sand.

\section{UCAPAN TERIMA KASIH}

Ucapan terima kasih disampaikan pada PT.Pertamina EP Asset 1 Field Jambi yang telah memfasilitasi penelitian ini dan segala bantuan teknis serta diskusi yang diberikan selama penelitian berlangsung. Bapak dan Ibu penguji tugas akhir, serta tim reviewer Jurnal Ilmu Fisika Universitas Andalas.

\section{DAFTAR PUSTAKA}

Arifien, H., 2010, Inversi Seismik Berbasik Model Untuk Karakterisasi Reservoir: Studi Kasus Haurgeulis, (Skripsi), Jurusan Fisika, Fakultas MIPA, Universitas Diponegoro, Semarang.

Burge, D.W., Neff D.B., 1998, Well-based Seismic Lithology Inversion for Porosity and Pay-thickness Mapping, The Leading Edge, February Issue.uta

Koesoemadinata, R.P., 1980, Geologi Minyak- dan Gasbumi, Edisi Ke-2, Institut Teknologi Bandung, Bandung.

Novarie, 2009, Karakterisasi Reservoar Menggunakan Analisa Atribut Seismik Untuk Lapangan Mendawai, Jawa Barat Utara, (Skripsi), Departemen Fisika, FMIPA, Universitas Indonesia, Jakarta.

Sukmono, S., 2002, Interpretasi Seismik Refleksi, Departemen Teknik Geofisika, Institut Teknologi Bandung, Bandung.

Tabah, F.R, 2010, Inversi Model Based Untuk Gambaran Litologi Bawah Permukaan, Jurnal Sains \& Matematika (JSM), Vol.18, No.3, Lab.Geofisika, Jurusan Fisika, Universitas Diponegoro, hal.88-93.

Tullailah, N.N., Lantu dan Aswad, S., 2015, Karakterisasi Reservoar Karbonat Menggunakan Analisis Seismik Atribut dan Inversi Impedansi Akusti (AI) Pada Formasi Kais Lapangan "NNT" Cekungan Salawati Papua, UNHAS Repository, Jurusan Geofisika, Universitas Hasanuddin.

Yaman, I.H, 2005, Lithology Classification Using Cluster Analysis Of Generalized Principle Components Of Seismic Attributes: A Case Study In Boonsville Area. Proceeding Joint Convention HAGI-LAGIPERHAPI, Surabaya. 